\title{
ПЕРЕВАГИ ОПЕРАЦІЙНОГО ДОСТУПУ “СLAMSHЕLL" В ХІРУРГІЇ ГРУДНОЇ АОРТИ
}

\author{
๑В. С. Мороз, Р. Й. Лекан, Т. В. Романюк \\ КНП «Тернопільська університетська лікарня» ТОР
}

РЕЗЮМЕ. В статті на основі практичного досвіду складних клінічних випадків розглянуто проблему вибору оптимального операційного доступу в хірургії грудної аорти. Врахувавши загальновідому об'єктивну оцінку якості доступу за методом А. Ю. Созон-Ярошевича, з'ясовано, що саме операційний доступ "сlamshell» вирізняється кращим інтраопераційним візуальним котролем важкодоступних зон грудної порожнини, що підвищує ефективність реконструктивної хірургії висхідної частини, дуги аорти та ії гілок при поширеному їі ураженні на низхідну аорту.

КлючовІ СлОВА: аневризма грудного відділу аорти; двоплевральний хірургічний доступ.

Вступ. Аневризми грудного відділу аорти (АГА) - це аномальне розширення аорти вище діафрагми. Дотепер АГА є однією зі складних і не повністю вирішених проблем серцево-судинної хірургії. АГА складають 1/4 від усіх аневризм аорти. Локалізація АГА у висхідній частині складає 40 \%, дузі аорти - $10 \%$, низхідній аорті - 30 \%. Торакоабдомінальна аневризма аорти (ТААА) складає $15 \%$, різні комбінації уражень грудної аорти - 4 \%, а мегааорта (аневризматичне ураження всієї грудної аорти (ГА)) - близько $1 \%$.

На сьогодні частота АГА складає, в середньому, 6 випадків на 100000 населення і продовжує збільшуватися через зростання тривалості життя та покращення діагностичних можливостей. Також актуальність проблеми зумовлена високою госпітальною летальністю, низькими показниками виживання у віддалені терміни спостереження, що пов'язано з вихідним тяжким станом пацієнтів, відсутністю єдиних критеріїв у тактиці ведення, що визначає вибір того чи іншого методу лікування, терміни і оптимальний об'єм реконструктивної операції, та умовами її забезпечення. Однією із найважливіших умов якісного виконання операцій при АГА та ТААА $є$ правильний вибір хірургічного доступу. Ці операції можуть виконуватися через серединну стернотомію, передньобокову, задньобокову та повну торакотомію, через двоплевральний доступ («clamshell» - відкрита мушля), та за допомогою торакофренолапаро/люмботомії [1].

Мета - оптимізація доступу до АГА при протяжному ураженні аорти.

Матеріал і методи дослідження. В Університетській лікарні Тернополя ми прооперували двох пацієнтів з аневризмами аорти різних локалізацій. У пацієнта М. діагностовано гігантську сифілітичну аневризму дистальної частини дуги та третини низхідної частини грудної аорти. Виконано резекцію аневризми та протезування дистальної частини дуги аорти від лівої загальної сонної артерії до наддіафрагмальної частини аорти з ре- імплантацією лівої підключичної артерії в дугу аорти за допомогою окремого протеза.

Пацієнт К. був оперований ургентно з приводу гострого розшарування аорти типу А. У пацієнта був діагностований синдром Марфана з аневризмою висхідної аорти, з приводу чого він був оперований планово в 2002 р. Йому було виконано операцію Бентала. На момент розшарування було виявлено: значне розширення залишку висхідної аорти, дуги аорти та третини низхідної частини грудної аорти. Пацієнту було проведено заміну залишку висхідної аорти, всієї дуги та третину низхідної частини грудної аорти. Реімплантація дуги аорти проводилася на «малій» латі Кареля брахіоцефальний стовбур (БЦС) та лівій загальній сонній артерії (ЛЗСА). Ліва підключична артерія реімплантована окремо в протез висхідної аорти. При зігріванні пацієнта ми отримали розшарування БЦС з оклюзією правої загальної сонної артерії. Це змусило повторно провести операцію на дузі аорти з повним окремим переключенням брахіоцефальних артерій.

Результати й обговорення. На сьогодні відмічають ряд положень, що лежать в основі раціонального операційного доступу до аорти та її гілок [2].

1. Вибір розрізу, що має найкоротший шлях до об'єкту втручання. На розмір і рівень розрізу в основому впливає протяжність ураження аорти.

2. Забезпечення достатнього оперативного простору в рані.

3. Стабільна та адекватна експозиція оперативного об'єкта в рані.

4. Малотравматичність розрізу, збереження великих судинно-нервових утворень і мінімальна травматизація м'язів грудної клітки та живота.

5. Забезпечення, при необхідності, розширення доступу під час операції.

6. Можливість активного ведення хворого в післяопераційному періоді.

Об'єктивна оцінка якості доступу проводилась згідно з методом А. Ю. Созон-Ярошевича. 
Огляди літератури, оригінальні дослідження, погляд на проблему, випадок з практики, короткі повідомлення Визначали три критерії доступності об'єкта операції: 1) глибина рани (ГР); 2) кут операційної дії (КОД); 3) кут нахилу осі операційної дії (КНООД).

КОД вимірювався вершиною конусу, який утворений двома лініями, що проведені з точки, яка $є$ важливим хірургічним об'єктом, до країв хірургічної рани. КОД відображає маневреність рук хірурга та хірургічного інструменту в операційній рані. Так, при КОД $90^{\circ}$ операція в глибині рани проводиться так само легко, ніби оперований орган знаходиться на поверхні. При КОД $25^{\circ}$ оперативне Втручання $є$ утрудненим, а при КОД $10^{\circ}$ - неможливим.

КНООД визначає умови, від яких залежить зручність хірургічного втручання. Цей кут утворюється віссю операційної дії і площиною ранової апертури. За напрямок осі операційної дії береться лінія, яка з'єднує очі хірурга з точкою об'єкта хірургічного втручання. Важливість КНООД полягає в тому, що він показує, наскільки проекція доступу відповідає місцю оперативного втручання. Найбільш оптимальним вважається КНООД, коли він дорівнює $90^{\circ}$. При зменшенні цього кута огляд об'єкта операції і маніпуляції хірурга утруднені.

Доступ «clamshell», використовується не дуже часто, 6о асоціюється з підвищеною травматичністю: розкриття обох плевральних порожнин, зміщення органів середостіння при розведенні країв рани та багато ускладнень в післяопераційному періоді. Але він $є$ незамінним у грудній онкохірургії для виконання радикальних операцій при великих пухлинах середостіння, в кардіохірургії при трансплантації серцево-легеневого комплексу та трансплантації обох легень at-block та при пораненнях серця у військово-польовій хірургії. Також цей метод використовується в хірургії грудної аорти, особливо коли ураження захоплює кілька її анатомічних відділів.

Доступ виконується в положенні хворого на спині з розведеними руками. Розріз планується

\section{ЛІТЕРАТУРА}

1. Бокерия Л. А. Хирургия аневризм грудного и торакоабдоминального отделов аорты / Л. А. Бокерия, В. С. Аракелян, 2011.

\section{REFERENCES}

1. Bokeriya, L.A., \& Arakelyan, V.S. (2011). Khirurgiya anevrizm grudnogo $i$ torakoabdominalnogo otdelov aorty [Surgery of aneurysms of the thoracic and thoracoabdominal aorta]. [in Russian].

від середньої аксилярної лінії зліва до передньої аксилярної лінії справа нижче грудних залоз. Розсікають шкіру, підшкірну жирову клітковину та фасцію з м'язами. Після цього мобілізовані тканини зсувають доверху до необхідного рівня. По верхньому краю V ребра проводять торакотомію з обох сторін. Прошивають та перев'язують внутрішні грудні артерії і поперечно пересікають груднину. Двома ранорозширювачами розводять грудну клітку, одночасно розпрепаровуючи клітковину середостіння. При цьому відкривається доступ до дуги аорти, а при повороті стола вправо і відведенні лівої легені допереду - до всієї низхідної частини грудної аорти. Після відкриття перикарда відкривається доступ до висхідної аорти та серця [3].

Орієнтирами для визначення параметрів хірургічного доступу були праве передсердя, аортальний клапан, висхідна аорта, брахіоцефальний стовбур, ліва підключична артерія, перешийок аорти, аорта на рівні VII ребра та аорта на рівні діафрагми.

Просторове відношення в рані при доступі «clamshell» відповідає необхідним вимогам до операційного доступу по всі параметрах, окрім низхідної частини аорти. Найгірші показники у відношенні аорти на рівні діафрагми: велика ГР та критичні КОД і КНООД. Тому, рекомендовано операцію на висхідній та дузі аорти виконувати стоячи справа біля операційного стола при його горизонтальному положенні, а маніпуляції на низхідній аорті краще виконувати знаходячись зліва від хворого при повороті стола на 30-40 від хірурга. При цьому показники просторових відношень в рані відносно низхідної частини грудної аорти суттєво покращуються.

Висновок. Доступ «clamshell» $\epsilon$ ефективним для реконструктивної хірургії висхідної частини та дуги аорти, її гілок при поширеному її ураженні на низхідну аорту. 
КНП «Тернопольская университетская больница» ТОС

РЕЗЮМЕ. В статье на основе практического опыта сложных клинических случаев рассмотрена проблема выбора оптимального операционного доступа в хирургии грудной аорты. Учитывая общеизвестную объективную оценку качества доступа по методу А. Ю. Созон-Ярошевича, установлено, что именно операционный доступ «clamshell» отличается лучшим интраоперационным визуальным котролем труднодоступных зон грудной полости, повышает эффективность хирургии восходящей части, дуги аорты и ее ветвей при распространенном ее поражении на нисходящую аорту.

КЛючЕВЫЕ СЛОВА: аневризма грудного отдела аорты; двуплевральный хирургический доступ.

\section{ADVANTAGES OF CLAMSHELL SURGICAL ACCESS IN THORACIC AORTIC SURGERY \\ @V. S. Moroz, R. J. Lekan, T. V Romanyuk Ternopil University Hospital}

SUMMARY. The problem of choosing the optimal surgical access in thoracic aortic surgery is considered in the article on the basis of practical experience of complex clinical cases. Given the well-known objective assessment of the quality of access by the method of A. Yu. Sozon-Yaroshevich, it was found that the operative access "clamshell" is characterized by the best intraoperative visual control of hard-to-reach areas of the thoracic cavity, which increases the effectiveness of reconstructive surgery of the ascending part and the aortic arch, its branches with widespread damage to the descending aorta.

KEY WORDS: thoracic aortic aneurysm; double pleural surgical access.

Отримано 22.05.2020 